\title{
Routes to Remembering: Lessons from al Huffaz
}

\author{
Mariam Adawiah Dzulkifli \\ Associate Professor of Psychology (corresponding author), Department of Psychology, KIRKHS \\ International Islamic University Malaysia, Kuala Lumpur, Malaysia; m.adawiah@iium.edu.my
}

\author{
Abdul Wahab bin Abdul Rahman \\ Professor of Computer Science, Department of Computer Science, KICT \\ International Islamic University Malaysia, Kuala Lumpur, Malaysia \\ Jamal Ahmed Bashier Badi
}

Professor of Islamic Revealed Knowledge, Department of General Studies, KIRKHS International Islamic University Malaysia, Kuala Lumpur, Malaysia

\author{
Abdul Kabir Hussain Solihu \\ Associate Professor of Islamic Revealed Knowledge, Department of General Studies, KIRKHS \\ International Islamic University Malaysia, Kuala Lumpur, Malaysia
}

\section{Doi:10.5901/mjss.2016.v7n3s1p121}

\section{Abstract}

Al Quran is the basis for all aspects of Muslim's life. These words of Allah are to guide us in every phase of our journey to become ummatan wasata including teaching and learning. Remembering is essential in one's attempt to learn. Remembering involves one core cognitive process known as memory. This research aims to explore and form a better understanding on the cognitive basis underlying human memory, so as to help in optimizing one's own ability to learn. We have chosen to study the memory of Al Huffaz, i.e. those who memorize the Quran because of their exceptional memory performance to commit such a volume in their memory. In the Western literatures, the most influential research on people with superior memory performance focused mainly on chess players (Chase \& Simon, 1973). In our context Al Huffaz are considered as people with superior memory performance due to the greater body of knowledge, the possession of accurate memory and superior ability to store information in memory. The exceptional memory ability of the Al Huffaz was investigated via a detailed and structured interviews and a survey. The findings from the interviews strengthened the involvement of several control processes such as rehearsal, motivation or interest and self-discipline. In addition, the findings from the survey revealed that the best predictor to memorizing ability is the self- efficacy and goal setting behavior. The understanding on this cognitive basis underlying human memory will definitely help to develop ummatan wasata mentioned in the Quran become a reality.

Keywords: Memory performance, Huffaz, self-efficacy, rehearsal, goal setting behaviour

\section{Introduction}

Remembering is essential in one's attempt to learn. Information learned has to be sent, stored and remembered. According to Gredler (2009) learning is an active process that involves the transfer of information from the environment to the brain. Information is retained and undergoes more processing to make it available later or to bring back the specific information when it is needed. Thus, theoretically, learning is the capability of modifying information already stored in memory based on new input or experiences that result in relatively permanent change in behavior and mental processes. Hence, learning and remembering are contingent one another.

Remembering involves one core cognitive process known as memory. Memory is our mental process that gives us instant access to our personal past, complete with all of the facts that we know and the skills that we have cultivated. Human memory processes involve three primary stages namely encoding, storage and retrieval. During the encoding stage, information is sent to the brain and will be processed and transduced into neural form by an ensemble of brain cells. In the storage phase of memory formation, the brain must retain encoded data over extended periods of time. 
Retrieval constitutes the access to the infinite world of stored information, where we bring stored information out of permanent memory back into working memory, which can be mentally manipulated for usage.

Memory is also conceptualized in term of its structures. In one of the most influential models of human memory proposed by Atkinson and Shiffrin (1968), memory is made up of three structures namely sensory register store (SRS), short-term store (STS) and long-term store (LTS). These three memory structures differ in terms of the capacity to hold information and the duration of the information retention. SRS can hold a huge amount of information available from all the senses but the information there only retains for seconds or less. The second memory structure is the STS which is characterized as a limited capacity system for temporary storage. The information in the STS can only be retained for a very short period of time, approximately $15-30$ seconds (Atkinson \& Shiffrin, 1968). The third structure in the model of memory proposed by Atkinson \& Shiffrin (1968) is referred to as LTS which has unlimited storage capacity and able to hold information in a long time period.

An important aspect of human memory highlighted by Atkinson and Shiffrin (1968) is the control processes, which according to Atkinson \& Shiffrin (1968) influences the flow of the information between the memory structures. Memory control processes are active processes that can be controlled by the person and may differ from one task to another (Goldstein, 2012). Rehearsal, mnemonics, heuristic, imagining, coding and modifying information are important control processes that allow the information to stay longer in one memory structure or be transferred from one structure to another memory structure. Attention is also one of the control processes that enable the selection as well as limiting the amount of information to be stored in STS (Reed, 2009). If attention is absent, the information in the SRS cannot be transferred to STS and it will cause the information to be lost (Atkinson \& Shiffrin, 1968). Thus, with attention information from SRS can be successfully transferred to STS. Another control process such as rehearsal is required to ensure that the information in the STS are well maintained and able to transferred to a more permanent storage (Reed, 2009). In short, all these various control processes allow an active interaction between the new and the stored information. They are the essential processes that become the basis for information transfer between different memory structures.

The current research is conducted with the aim to explore and form a better understanding on the cognitive basis underlying human memory. In particular, it is to discover the uniqueness of the memory ability of people called Huffaz. Huffaz is an Arabic word that is used to refer to people who have completely memorized all the thirty juzuk of the Quran. What could be memory processes and the predictors of their exceptional and superior memory performance? A direct implication of understanding the working of the experts' memory is it will help to form a better understanding on the cognitive basis underlying people with exceptional memory ability as well as the understanding of the structure and limits of human adaptation and learning.

\subsection{Memory in Islam}

The role played by human memory is so significant from Islamic point of view. In Islam, the main mode for the preservation of the Quran is through memorization. In the field of hadith, memory plays important role in determining the authenticity of a hadith. An authentic hadith according to Ibn Salah is the one which "has a continuous isnad (chain of narrators), made up of reporters of trustworthy memory from similar authorities, and which is found to be free from any irregularities (i.e. in the text) or defects (i.e. isnad)". For those studying hadith it is generally understood that the more trustworthy and of good memory the reporters, the more authentic is the hadith. Due to the significant role one's memory plays, muhaddith are very particular and careful in selecting hadith by checking up the memory of the individuals they took the hadith from. This is done to ensure the contents are not distorted unintentionally due to the difficulty caused by memory related problems. For instance, even if the narrator manages to fulfill the criteria of a fine narrator such as just and Muslim, but lack in memory performance, not only the narrator will be deemed as weak, even the hadith narrated is considered weak. This shows how memory alone can determine the status of a hadith. In the field of figh or Islamic jurisprudence, memory serves as a tool to implement Islamic laws and the protection of Muslim's well-being efficiently. For example when a Muslim is giving a testimony towards others in the case of qazf (accusation of adultery) their testimony shall be checked with the details given along their memory condition.

\subsection{Quranic memorization}

The tradition of Qur'anic memorization is traced back to the period of Prophet Muhammad (peace be upon him). In fact, Prophet Muhammad (peace be upon him) is indeed the first person who memorized the Qur'an as he was asked to commit the first revelation (96: 1-5) via the form of oral transmission by the Jibrail. In one of the hadith Prophet Muhammad (peace be upon him) shared with his companions the experience he went through when the revelation was 
sent to him.

Narrated by Said Bin Jubair:

It is for us to collect it and to give you (O Muhammad) the ability to recite it (the Qur'an) (75.16-17) which means that Allah will make him (the Prophet) remember the portion of the Qur'an which was revealed at that time by heart and recite it. Afterwards, Allah's Apostle used to listen to Gabriel whenever he came and after his departure he used to recite it as Gabriel had recited it."

Sahih Bukhari Volume 1, Book 1 No. 4

Prophet Muhammad (peace be upon him) often encouraged his companions to memorize the Quran since the majority of them cannot read nor write, leaving memory as the only thing they can depend on to preserve the Quran. Thus, memorization can be considered as one of the modes to preserve the authenticity of the Quran as the guidance to mankind historically.

With regard to Quranic memorization, several terms are to be clarified. Hifz is the Arabic word that refers to the process of memorizing the Quran. The books Mu'jam al Arabi al-Asasi and Mu'jam al-Wasit (as cited in Abdul Hafiz Abdullah \& Hasimah Muda, 2003) both explain that hifz means to guard or protect and to preserve from being lost. Thus, when applied to memorizing the Quran, it entails several processes that need to be carried out to ensure the information committed to memory is not lost. These processes include encoding the text of the Quran, rehearsing the text for the purpose of permanent storage and retrieving the text of the Quran with full accuracy and correctness. Hifz is therefore cannot be passive memorization process. Rather it is a highly active and complex memory-based task conducted by one so as to 'preserve' the Quran in an individual's memory.

The person who does the hifz is called hafiz (plural is huffaz). The word hafiz comes from the same root word as hifz and literally means guardian. The hafiz is commonly conceptualized to refer to the one who does the memorization of the Quran and thus becomes the guardian and preserve the Quran. In Malaysia, the term hafiz is understood to be one who has completely memorized all the thirty juzuk of the Quran.

Malaysia recorded 13,000 huffaz in 2011 (Penyelaras Pembangunan Al-Quran JPAQ, 2011). There are also 158 tahfiz (Quranic memorisation centers) registered with JAKIM (Jabatan Kemajuan Islam Malaysia, 2014). Over the years, many more informal centers have been formed too.

Research on memorization of Quran in Malaysia has revolved mainly around the various techniques used at different centers of tahfiz and the effectiveness of these methods (Sedek Ariffin \& Zulkifli Mohd Yusoff, 2014; Azmil Hashim, Ab. Halim Tamuri, Misnan Jemali \& Mohd Aderi Che Noh, 2013; Azmil Hashim \& Ab. Halim Tamuri, 2012; Mohamad Marzuqi Abd Rahim, 2008; Abdul Hafiz Abdullah \& Hasimah Muda, 2003). For example, the methods the various schools generally employed are fundamentally repetition (takrir) over a span of at least a year, to memorize verse after verse. They differ in details of techniques like the order of memorization of the 30 juzuk, the order of page memorized first, number of times students are required to repeat the verses and how revision is done i.e. after a week or a month and individually or by peer-review (tadarrus). These details serve as measures to ease the process and improve retention (Abdul Hafiz Abdullah \& Hasimah Muda, 2003; Sedek Ariffin \& Zulkifli Mohd Yusoff, 2014). These studies do address the much asked question on how to best memorize, but few have looked into the psychology of the process of memorization to understand how it happens.

As with the study on memory processes, it has been generally agreed that storing and retrieving information from memory involves bidirectional transfer of information across multiple memory domains (Atkinson \& Shiffrin, 1968, Cowan, 2000, Goldstein, 2011). However, there is less agreement on the nature of control processes that may become the basis for the information transfer. The current initiative is an attempt to discover and characterise the nature of the processes underlying the transfer of information between these memory structures. In particular, the control processes involved in memorizing the Quran by the huffaz.

\section{Method}

Methods for data collection were of two types; the first is a structured and detailed interview with subject matter experts. The interviews were conducted to explore the possible factors or processes influencing the process of memorization of the Quran. In an attempt to view the process holistically, the interview questions included open-ended questions on the possible human factors (iman or faith, self-discipline, age etc.), environmental factors (food, adaab or etiquettes like facing the qiblah etc., place), memory control processes (repeating, writing, understanding, etc.) and Quranic text characteristics (rhythm, writing style etc.). 
The second method for data collection is the survey on people who are involved in the Quranic memorization process. This was conducted on those who were involved in Quranic memorization with the aim to strengthen the findings from interviews as well as to explore on the best predictor for memorizing ability.

\subsection{Participants}

The participants to the interview consisted of five Huffaz. They were two Malaysian females and three males (one from Pakistan, one from Sudan and one from Malaysia). Their age ranged from 35 to 55 years old. All of them had completed memorizing the Quran and had more than three years of experience in the teaching and learning of memorization of the Quran.

As for the survey, the respondents consisted of 270 students from six tahfiz schools in Kuala Lumpur and Selangor. 52.2\% were females while the rest were male respondents. Their age ranged from 13 to 18 years old.

\section{Results}

\subsection{Findings from interviews}

The interviews were conducted to explore the possible factors or processes influencing the process of memorization of Quran. On the basis of the content analysis of responses given by the subject matter experts, the followings are the factors that have been identified and are believed to influence the memorization of the Quran. These factors have been arranged according degree of importance.

\subsubsection{Memory control processes.}

Memory control processes are active processes that can be controlled by the person and may differ from one task to another (Goldstein, 2012). Rehearsal, coding and imaging are some of the important control processes that govern the flow of information in human memory system. One of the most commonly used control processes is rehearsal. It refers to the process of repeating information either overtly or covertly. It may delay the loss of information from memory system or result in an increase in the memory strength. Rehearsal has been shown not only to maintain information in short term memory but also to control transfer of information from short term memory to long term memory (Atkinson \& Shiffrin, 1971).

At the outset, it was expected that rehearsal would be advantageous to memorization. The findings from the interviews strengthened this when all the interviewees mentioned on the importance of rehearsal as a memory control process in the process of memorizing the Quran. Interestingly, all the interviewees stressed that it is the maintenance and not elaborative rehearsal that plays the most important role in the memorization of the Quran. Maintenance and elaborative rehearsal are the two types of rehearsal that differ in that the former involves memorization of information by merely repeating the information without any consideration to its meaning or associating it with other information. This type of rehearsal involves a relatively superficial level of information processing. On the other hand, elaborative rehearsal is repeating with understanding, i.e. memorizing information by knowing its meaning and linking it to information already stored in long term memory. Compared to maintenance rehearsal, elaborative rehearsal involves a deep level of information processing. This is supported by Craik and Lockhart (1972) who argued that the processes involved in memory were more important than the memory structures. Thus, the deeper the level of information processing, the longer the information is kept stored and the better is the memory performance.

The finding from the interview however, gives more support to maintenance rehearsal as one of the main factors that contributes to successful long-term retention and accuracy of the Quranic verses.

\subsubsection{Motivation}

The content analysis from the interview suggested that the second pre-requisite to successful Quranic memorization is motivation. The interviewees described motivation as a mechanism that influenced what strategies the memorizer would use and how they follow through with it. This is actually in line with many motivation theorists that assume that motivation is necessary for the performance of any learned response (Huitt, 2011). This motivational factor is deemed important as it influence a relatively more effortful activity to complete the task. 


\subsubsection{Self-discipline}

Corresponding to motivation, another human factor i.e. self-discipline was also reported to be instrumental in finishing memorization of the 30 juzuk of Al Quran. Memorization of the Quran does involve deliberate practice. Ericsson and Charness (1994) described deliberate practice as the structured, arduous activity intended to improve performance and this practice was limited to a short length of time practised daily due to the enormous effort it needed. Thus, the memorizer would need discipline to practise as such.

Overall, the findings from the interview showed that consistent repetition or maintenance rehearsal, motivation and self-discipline were found to be impertinent to memorization of the Quran.

\subsection{Findings from survey}

The second part of data collection is a survey on people who are in the process of memorizing the Quran. The survey was conducted with the aim to strengthen the findings from interviews as well as to explore on the best predictor for memorizing ability. The items in the survey include those such as age, number of years being a hafiz, strategies to memorize, perception on memory ability, goal-setting behaviour, time management, self-efficacy, supportive environment and religiosity.

On the basis of regression analysis, seven predictors (age, number of years being a hafiz, goal setting, time management, memorising self-efficacy, supportive environment and religiosity) have been identified and there is one criterion variable (memorising al-Quran ability) (see Table 1). To test this model, first, a pre-investigation on the correlation between predictors and the memorising ability was investigated to ensure that all of the predictors were significantly related to the outcome variable (Tabachnick \& Fidell, 2007). The correlation analyses indicated that only memorising self-efficacy and goal setting were significantly correlated to the memorising ability and therefore these two predictors were included in the regression model.

Second, a hierarchical Multiple Regression Analysis (MRA) was conducted to test whether memorising selfefficacy and goal setting significantly predict the memorising ability (Field, 2005; Green \& Salkind, 2005). Memorising self-efficacy was entered in step 1, while goal-setting was entered in step 2. Results showed that memorising self-efficacy significantly predicted the memorising ability (Model $1: \mathrm{R}=.320, \mathrm{R}^{2}=.103$, Adjusted $\mathrm{R}^{2}=.099, \Delta \mathrm{F}(1,261)=29.824, \mathrm{p}=$ .000 ). And goal setting also significantly predicted memorising ability (Model 2 : $R=.364, R^{2}=.133$, Adjusted $R^{2}=.126$, $\Delta F(1,260)=9.056, p=.000)$. With the significant $\Delta F$, the findings indicated that memorising self-efficacy and goal setting were significant predictors to the memorising ability.

In addition to hierarchical regression, relative weight analysis was conducted to examine the exact amount of unique contribution the memorising self-efficacy and goal setting make to the outcome variable (memorising ability). While the former is a conventional tool to assess predictive validity, the latter is a recent technique used to examine the relative contribution each predictor uniquely makes in explaining the outcome variable (LeBreton, Hargis, Griepentrog, Oswald, \& Ployhart, 2007; LeBreton \& Tonidandel, 2008). Results of the relative weight analysis revealed that memorising self-efficacy was the strongest predictor to memorising ability as it explained $57.85 \%$ of the variance in memorizing ability. This was followed by the goal setting which explained $42.15 \%$ of the outcome variable.

Table 1.

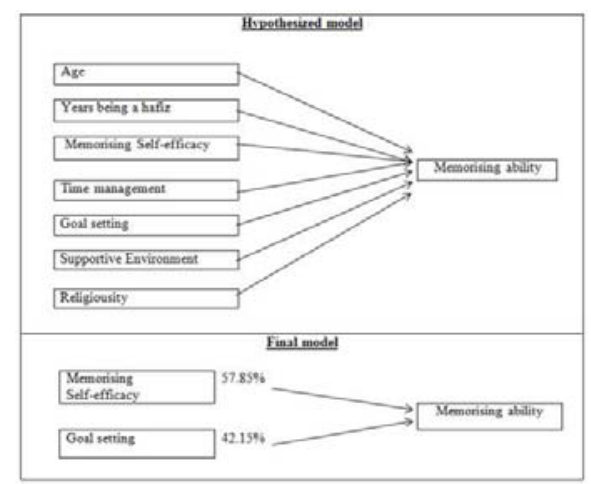




\section{Discussion}

The current chapter highlight on the current initiative to study people whose memory performance is of exceptional level. The study of the memory of the Huffaz was conducted with the aims to discover the factors that contribute to their superior memory performance in memorizing the Quran. The findings from the research are pragmatic and applicable to learning process in general and not necessarily memorizing the Quran or any other religious texts. Theoretically, learning involves memory. New information has to be remembered and information already stored in memory can be changed or modified in response to new input or experiences. In other words, learning is contingent on memory. It is therefore crucial for us to discover ways to optimise our memory ability so as to optimise our learning ability. The findings from the current research can help to form a better understanding of the cognitive basis underlying human memory, which can optimize human potential and lead to better interventions at schools of tahfiz all over the world. In addition, they can also be applicable to all knowledge and learning process that entails long-term and working memory.

The current research is divided into two phases. The first phase is an exploratory in nature. The structured and detailed interviews were conducted with several subject matter experts. In the second phase a survey was conducted on secondary school children who were involved in memorization of the Quran.

The findings from the interview revealed the importance of specific memory control process such as rehearsal. More importantly, it has been found that it is maintenance and not elaborative rehearsal that plays the most important role in the memorization of the Quran. Motivation and self-discipline have also been found to be essential in Quranic memorization.

Up till now, there seemed to be a dichotomy between two approaches to memorization where the traditional was repetition and thus considered conservative by psychologist. These psychologists hold on to the results of numerous researches that show that elaborative rehearsal is a more effective method of studying and memorization (Craik and Lockhart, 1972, Craik and Tulving, 1975). However, much insight has been gained into the process of memorization from the current findings. In memorizing the Quran, maintenance rehearsal is better compared to elaborative rehearsal. It can be said that memorization of the Quran is different because it entails memorization of a large volume of text, more often than not, incomprehensible to the memorizer. Thus, it needs to be categorized differently and in fact, can be better understood as a process to gain expertise in the text of the Quran. Unlike studying which, requires understanding of concepts for higher order executive functions, memorization of the Quran focuses on the preservation of the Quranic text 'as it is'. This difference in goal may lead to differences in the memory control process used. In addition, the voluminous amount of material to be rehearsed verbatim makes it hard to use elaborative rehearsal as a control process except for in a more superficial manner as used for memorization of numbers by expert memorizers.

The findings from the survey indicated that the best predictor to memorizing ability is self-efficacy and goal-setting behavior. Self-efficacy refers to the beliefs that one has concerning his capabilities to attain designated levels of performance (Bandura, 1986, 1988). Kanter (2006) referred self-efficacy as a kind of self-confidence while Brockner (1988) proposed that it is a task-specific version of self-esteem. One's self-efficacy is closely related to goal-setting behavior as one's capability of achieving can influence his or her learning ability. The influence can be in the form of the goals set by the learners to attain, the efforts that the learners are willing to exert and the level of persistence in dealing with challenges.

Self-efficacy has been found to be the determinant to any task performance (Bandura \& Locke, 2003). With regard to memory performance, Beaudoin, Marine, Desrichard \& Olivier (2011) in their meta-analysis study reported on the significant positive correlation between memory self-efficacy and memory performance. This is in line with the findings from the current study that revealed memory self-efficacy as one of the best predictors in memorizing ability. In memorizing the whole Quran, memorizing self-efficacy is deemed important and necessary as the Quran itself is a large volume of text, more often than not, incomprehensible to the memorizer. The Quran is a

\footnotetext{
"...divine religious book of Islam. Muslims believe that it contains the actual words of Allah (the God), and that it is the last scripture from Him to humankind. It was revealed to Prophet Muhammad 14 centuries ago in pure classical Arabic language consisting of 77,430 words, which are organized in 30 sections (Juzuk). The 30 juzuk is further categorized to 114 chapters (Surahs) that are in turn partitioned into a number of verses (Ayah). The Quranic text is unique and has not encountered any change throughout the previous decades. It is also considered the main source of legislation in Islam since it contains the main rules that govern Muslim in various spiritual, private, social and political aspects of life." (Alrabiah, Alhelewh, Al-Salman \& Atwell, 2014, pp. 1 \& 2).
}

To summarize, among the possible routes to remembering revealed from the current research are one's memory control processes which include rehearsal, motivation and self-discipline. The belief in one's ability to succeed in 
memorizing information or memory self-efficacy and goal-setting behavior have also been identified as the best predictor to memorizing ability. Consequently, any learners or educators should be vigilant on the need to look into the internal processes of the learners since these may be the key points to optimize one's potential. Future research may look into documenting the neural underpinnings of memory processing system as it would offer significant insights into the mechanisms of exceptional memory performance.

\section{Conclusion}

Those in learning world are inundated by massive amounts of information to attend to. Exchanges of information that occur in every second demand for the need to increase understanding on the the mechanisms and factors contributing to superior memory performance. There is indeed a great need for such studies in our efforts to improve memory and learning process in the general population and the memory impaired.

\section{Acknowledgement}

The research is funded by the Ministry of Higher Education under its Fundamental Research Grant Scheme (FRGS13019-0260).

\section{References}

Abdul Hafiz Abdullah \& Hasimah Muda. (2003). Kaedah hafazan al-Quran yang sistematik dan praktikal dalam melahirkan para huffaz yang rasikh (The systematic and practical methods of memorizing the Quran to produce huffaz). Pusat Pengajian Islam dan Sosial. Universiti Teknologi Malaysia (The Centre for Islamic Studies and Social, University of Technology, Malaysia).

Alrabiah, M., Alhelewh, N., Al-Salman, A.M., \& Atwell, E. (2014). An empirical study on the holy Quran based on a large classical Arabic corpus. International Journal of Computational Linguistics, 5 (1), 1-13.

Atkinson, R.C., \& Shiffrin, R.M. (1968). Human memory: A proposed system and its control processes. In K.W. Spence (Ed.), The psychology of learning and motivation: Advances in research and theory (pp. 89-195). New York: Academic Press.

Azmil Hashim, Ab. Halim Tamuri, Misnan Jemali dan Mohd Aderi Che Noh (2013). Hubungan antara strategi dalam gaya pembelajaran tahfiz dan pencapaian hafazan pelajar (The relationship between learning strategy and performance of memorizing students). International Journal of Islamic Studies and Arabic Language Education, 1(1), 34-43.

Bandura, A. (1977). Social learning theory. Englewood Cliffs, NJ: Prentice Hall.

Bandura, A. (1982). Self-efficacy mechanism in human agency. American Psychologist, 37, 122-147.

Bandura, A. (1986). Social foundations of thought and action. Upper Saddle River, NJ: Prentice Hall.

Bandura, A. (1997). Self-Efficacy: The exercise of control. New York, NY: W.H. Freeman.

Bandura, A. (2004). Cultivate self-efficacy for personal and organizational effectiveness. In E. A. Locke (Ed.), Handbook of principles of organizational behavior (pp. 120-136). Malden, MA: Blackwell.

Bandura, A., \& Locke, E. A. (2003). Negative self-efficacy and goal effects revisited. Journal of Applied Psychology, 88(1), 87-99.

Beaudoin, M., \& Desrichard, O. (2011). Are memory self-efficacy and memory performance related? A meta-analysis. Psychological Bulletin, 137(2), 211-241.

Braver, T.S., March, D.M., Kelley, W.M., Buckner, R.L., Cohen, N.J., Miezin, F.M., Synder, A.Z., Ollinger, J.M., Akbudak, E., Conturo, T.E \& Peterson, S.E. (2001). Direct comparison of prefrontal cortex regions engaged by working memory and long term memory tasks. Neurolmage, 14, 48-59.

Brockner, J. (1988). Self-esteem at work. Lexington, MA: Lexington Books.

Cowan, N. (2005) Working memory capacity. Hove, East Sussex, UK: Psychology Press.

Cowan N (2008) What are the differences between long-term, short-term, and working memory?, Program Brain Research, 169, 323338.

Craik, F.I.M., \& Lockhart, R.S. (1972) Levels of processing: A framework for memory research. Journal of Verbal Learning and Verbal Behavior, 12, 599-607.

Craik, F.I.M \& Tulving, E., (1975) Depth of processing and the retention of words in episodic memory. Journal of Experimental Psychology, 104, 268-294.

Engel de Abreu P.M.J., Gathercole, S.E., \& Martin, R (2011) Disentangling the relationship between working memory and long term memory: The roles of short term storage and cognitive control. Learning and Individual Differences, 21(5), 569-574.

Ericsson, Anders, Charness, Neil (1994) Expert performance: Its structure and acquisition. American Psychologists, 49(8), 725-747

Goldstein, E.B (2011) Cognitive Psychology. $3^{\text {rd }}$ Ed. Canada: Wadsworth

Gathercole, S.E. \& Baddeley, A.D (1993). Phonological working memory: A critical building block for reading development and vocabulary acquisition? European Journal of Psychology of Education, 8, 259-272.

Gredler, M. (2009) Learning and instruction: Theory into practice. Pearson Education, Inc: New Jersey.

Haberlandt, K. (1997). Cognitive psychology (2nd ed.). Boston, MA: Allyn \& Bacon. 
Holmes, J., Gathercole, S.E \& Dunning, D.L (2009) Adaptive training leads to sustained enhancement enhancement of poor working memory in children. Developmental Science, 12(4), 9-15.

Huitt, W (2011) Motivation to learn: An overview [Online]. Available: http://www.edpsycinteractive.org/topics/motivation/motivate.html

Kanter, R. M. (2006). Confidence: How winning and losing streaks begin and end. New

York, NY: Crown Publishing.

LeBreton, J.M., Hargis, M.B., Griepentrog, B., Oswald, F.L. \& Ployhart, R.E. (2007) A multidimensional approach for evaluating variables in organizational research and practice, Personnel Psychology, 60(2), 475-498

LeBreton, J. M, Tonidandel, S. (2008). Multivariate relative importance: Extending relative weight analysis to multivariate criterion spaces. Journal of Applied Psychology, 93, 329-345

Mohamad Marzuqi Abd Rahim (2008). Pengajaran Mata Pelajaran Hafazan Al-Quran: Suatu Kajian Maahad Tahfiz Al-Quran Zon Tengah. Kertas Projek Sarjana: Fakulti Sains Kognitif dan Pembangunan Manusia: Universiti Pendidikan Sultan Idris. (The teaching of hafazan subject: A case study on Maahad Tahfiz Al-Quran Zon Tengah. Master Dissertation: The Faculty of Science Cognitive and Human Development: Teaching University of Sultan Idris)

Raghubar, K.P., Barnes, M.A \& Hecht, S.A (2010) Working memory and mathematics: A review of developmental individual differences and cognitive approach. Learning and Individual Differences, 20(2), 110-122

Reed, S.K., (2009). Cognition: Theory and applications (8th ed). Belmont, CA: Wadsworth Cengage.

Sedek Ariffin, Zulkifli Mohd Yusoff. (2015). Metodologi hafazan al-quran (Methods of memorization of Al Quran). Malaysia: UM Press

Sedek Ariffin, Mohd Yakub @ Zulkifli Mohd Yusoff, Fauzi Deraman, Ishak Suliaman, Khadher Ahmad, Munirah Abd Razak, Faisal Ahmad Shah, Norhidayah binti Yusoff. (2014). Modul penghafalan al-quran berdasarkan tempoh 30 minit sehari (The Module to memorize the Quran based on 30 minutes daily). Malaysia: APIUM

Tabachnick, G. G., and Fidell, L. S. (2007). Experimental Designs Using ANOVA. Belmont, CA: Duxbury. 